\title{
Marie-Claire Bergère, Chine: le nouveau capitalisme d'État (China: The New State Capitalism),
}

Paris, Fayard, 2013, 310 pp.

\section{Nathan Sperber}

\section{OpenEdition}

\section{Journals}

Electronic version

URL: http://journals.openedition.org/chinaperspectives/6334

DOI: 10.4000/chinaperspectives.6334

ISSN: 1996-4617

\section{Publisher}

Centre d'étude français sur la Chine contemporaine

Printed version

Date of publication: 1 December 2013

Number of pages: $79-81$

ISSN: 2070-3449

\section{Electronic reference}

Nathan Sperber, « Marie-Claire Bergère, Chine: le nouveau capitalisme d'État (China: The New State Capitalism), », China Perspectives [Online], 2013/4 | 2013, Online since 01 December 2013, connection on 24 September 2020. URL : http://journals.openedition.org/chinaperspectives/6334 ; DOI : https:// doi.org/10.4000/chinaperspectives.6334

This text was automatically generated on 24 September 2020 .

(c) All rights reserved 


\section{Marie-Claire Bergère, Chine: le nouveau capitalisme d'État (China: The New State Capitalism),}

Paris, Fayard, 2013, 310 pp.

\section{Nathan Sperber}

Over the past few years, common interpretations of the chinese economy propounded in the West have undergone a shift of emphasis. Until quite recently, most media discourse and scholarly analysis were, at bottom, a variation on the theme of liberalisation. The focus was laid on China's societal transformation from socialism to a fully-fledged capitalist order, or in other words, on the deepening of the country's market transition. The validity and usefulness of such a perspective is hard to contest, and yet, as a prism through which to understand the present-day chinese political economy, the notion of liberalisation has become overly obvious, if not a shade simplistic. In effect, the market transition paradigm is being increasingly displaced in favour of its mirror image, namely an all-out

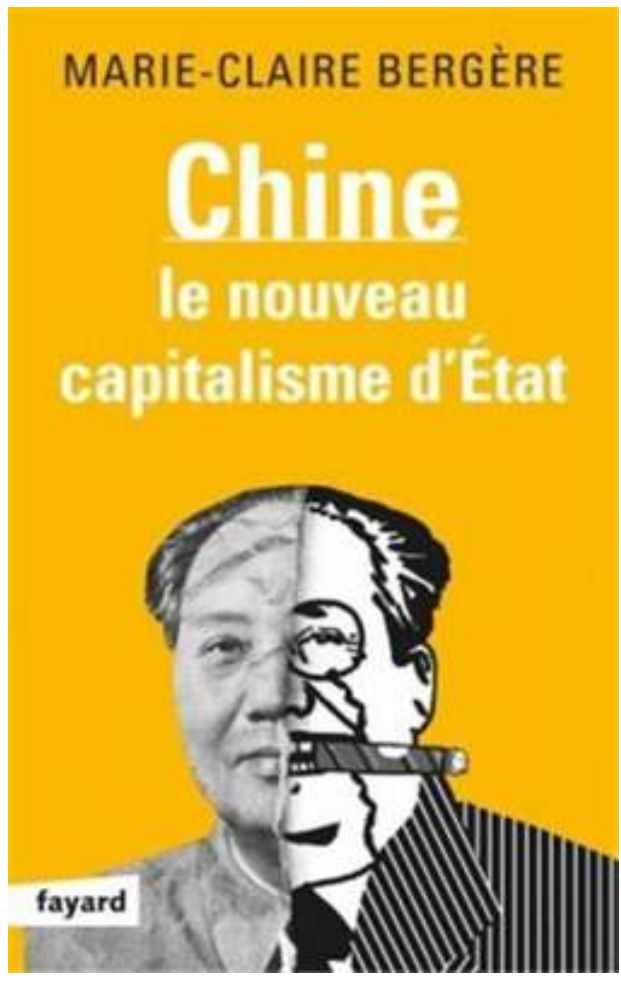
insistence on the dirigisme of the chinese state, ranging from state-owned enterprises (SOEs) to capital allocation, from the renminbi regime to industrial subsidies. 
2 The eerie resilience (so far) of the Chinese economy in the face of the worst global crisis since the Great Depression, combined with the inexorable ascent of China's top SOEs in the Forbes and Fortune international corporate rankings, have triggered no little soulsearching on Western shores. In 2010, Ian Bremmer's shocker book The End of the Free Market warned the American public of a global clash between the "market capitalism" of the West and the "state capitalism" of a handful of developing nations, among which China stood as primus inter pares. Bremmer's ideas, as unsubtle as they are incisive, have been liberally relayed in the mainstream economic press. To many ears, the terms "state capitalism" and "China" have now become a natural pair.

3 Have we simply witnessed the substitution of one stereotype for another? Probably. And yet, under the veneer of overused labels, essential issues are raised: how does the peculiar interpenetration of politics and economics in the PRC distinguish it from developed Western nations as well as from other post-socialist and emerging countries? How is it possible to discern the durable from the transitional among the constituent traits of China's economic statism? In sum, how do we elucidate the differentia specifica of the Chinese political economy?

In this connection, Marie-Claire Bergère's decision to focus her latest work on the role of the state in the Chinese economy is most timely. As smooth as it is knowledgeable, Chine: le nouveau capitalisme d'État embraces the thesis of state capitalism as its departure point. It then goes on to explore a number of other aspects of Chinese society, surveyed through the lens of the CCP's overarching dominance in the realms of economics, politics, and ideology.

5 The introduction, aptly titled "The end of illusions," sets the tone: to presuppose a spontaneous tendency towards economic or political liberalisation in China "implies a kind of determinism as thorough as in the Marxist schema" (p. 11). The book then proposes a short retrospective sketch of three decades of Reform and Opening (Chapter 1), followed by a description of the central workings of China's current "state capitalism" (Chapter 2). Bergère insists in particular on the "national champions," the central-level firms nominally under the control of SASAC, ${ }^{1}$ as well as on the rapid expansion of state-funded investment in the wake of the 2008 stimulus plan, a trend often referred to in China as 国进民退 (guo jin min tui, “the state advances, the private retreats"). Chapters 3 and 4 address the situation of the Chinese domestic private sector, a terrain very familiar to Bergère. The diverse, fragmented, and usually subaltern world of private entrepreneurs is sharply rendered, and the arresting thesis of an absent bourgeois class - "one finds in China neither a triumphant bourgeoisie, nor indeed any kind of bourgeoisie" (p. 133) - is as cogent as it was in Bergère's Capitalismes et capitalistes en Chine (2007). The internal structure of the CCP is then reviewed, together with its strategies of social control and repression that constitute the coercive side of party-society relations (Chapter 5). This is followed by an exploration of the Party's efforts at legitimation - the consensual aspect of partysociety relations - with a special emphasis on nationalist mobilisation (Chapter 6). Chapter 7 moves on to provide a critical survey of recent debates on the existence of a unique "model" of development with Chinese characteristics. Joshua Ramo's oft-cited "Beijing Consensus," launched in 2004, is increasingly out of fashion, replaced by the “China Model," or 中国模式, which has been the object of a flurry of publications in the PRC in recent years. It is unmistakably a more nationalist construct than the Beijing Consensus, and it is often accompanied by a rhetoric of identity. Bergère's work 
concludes with a chapter examining possible scenarios for the medium term. Reasserting the "institutional agility" of the regime (p. 283), Bergère predicts, with warranted circumspection, an "evolution" - as opposed to a breakdown - of the statecapitalist status quo.

Chine: le nouveau capitalisme d'État thus purports to be a panoramic enquiry into Chinese authoritarianism's multiple facets today. Although the author, a historian by trade, offers some penetrating insights derived from her past scholarship on the merchant strata in late Qing and Republican China, these remain quite short and peripheral. In terms of sources, Bergère relies in large part on a vast collection of news articles (notably from the New York Times), together with a number of secondary academic references (including the works of Barry Naughton, Nicholas Lardy, and Huang Yasheng). Prospective readers should be warned, however, of the relative dearth of first-hand material and analysis in the book.

7 Another note of warning should be made regarding Chine: le nouveau capitalisme d'État. This is not the most accomplished work of its author on the theoretical level, to say the least. Rather, it appears that a conscious choice was made to put readability over conceptual elaboration, with the aim of reaching out to a larger public. On its own terms, this is a success. Packed with information as it is, the book is a pleasant read, thanks in part to the author's trenchant prose style. A non-specialist reader eager to know more about a subject of such pressing relevance would be very well-advised to peruse it.

8 The same cannot be said, however, for those who were hoping for Marie-Claire Bergère to throw new conceptual light on an issue that remains bitterly under-theorised in China Studies. The expression "state capitalism," cited throughout, is never properly defined. As a result, it remains little more than a catchword, and vague and overworn at that. The very notion of "capitalism" would have deserved a better treatment. Thus we are told that "capitalism has never been the dominant form of the reformed Chinese economy" (p. 102), an assertion that will be difficult to gauge for anyone who is not familiar with Bergère's past scholarship, in particular Capitalismes et Capitalistes en Chine.

9 In addition to semantic issues of this kind, a minor confusion concerning the publicprivate nexus in the Chinese economy is apparent. The author seems to oscillate between two incompatible approaches. On the one hand, a static, dichotomistic perspective is implicit in the expression "mixed economy," which crops up multiple times, as well as in the rather hasty assertion that Huawei, the telecoms equipment giant founded by Ren Zhengfei, is "a fake private firm" (p. 77). On the other hand, this dualistic depiction of the public-private conundrum is fortunately debunked by Bergère herself only two pages later: "Let us abandon, for a time, our Cartesian logic [...] in China, not being public does not necessarily mean being private [...]" (p. 79); and also: "Chinese capitalism is characterised by [...] the tangling of statuses and the overlapping of categories." This last passage evinces the acuity and subtlety that Bergère has demonstrated so many times in her past research. One has therefore all the more reason to regret that she does not here attempt to explore the implications of being "public" and "private" in the Chinese context.

On a more trivial note, one finds a handful of inaccuracies that should have been prevented by less sloppy editorial work. To provide an example: it is written that "the grey economy [...] may represent RMB 9.3 billion ( $\$ 1.47$ billion) as of 2010.” A reference is made to TheNew York Times, but the proper source is surely the report produced by 
Wang Xiaolu for Crédit Suisse in 2010, which estimated the grey economy at RMB 9.3 trillion in 2008 - about 30 per cent of the Chinese GDP. ${ }^{2}$ Or this straightforward blunder: that the CCP was founded in 1921 in the former French concession of Beijing (p. 184).

11 Such weaknesses, most of them minor, should not detract from the overall quality of Marie-Claire Bergère's latest work. The book is highly informative and elegantly written; it addresses a topic of crucial relevance; and it comes from a scholar with tremendous research experience on the Chinese economy.

12 As this book review is being written, current events seem to be moving fast on the front of China's "state capitalism." The fifth generation of Chinese leadership took over the organs of government last March, and advocates of a new wave of economic reform are harbouring high hopes of liberalisation in view of the third plenum of the CCP Central Committee scheduled for this autumn. Last year, the oft-mentioned report China 2030, co-written by the World Bank and the Development Research Centre of the State Council, called for a deregulation of the financial sector together with a privatisation of state assets. A few Pekinologists believe that Li Keqiang is eager to push forward implementation of this report. We might soon be able to tell whether the so-called "state capitalism" of the PRC has passed its peak.

\section{NOTES}

1. The State-owned Assets Supervision and Administration Commission, in Chinese 国务院国有 资产监督管理委员会 or 国资委.

2. Wang Xiaolu, “Analysing Chinese grey income," Crédit Suisse, 2010.

\section{AUTHOR}

\section{NATHAN SPERBER}

Nathan Sperber is a Ph.D. candidate at the School for Advanced Studies in Social Sciences (EHESS, Paris), (nathan.sperber@gmail.com). 